\title{
"LOS JUZGA UN TRIBUNAL, LOS CONDENAMOS TODOS": DOS CONFLITOS PELAS MEMÓRIAS, MORALIDADES E VERDADE NOS TRIBUNAIS ARGENTINOS ${ }^{1}$
}

Liliana Sanjurjo

\section{Introdução}

Há mais de três décadas, o movimento de familiares de desaparecidos da ditadura militar argentina (1976-1983) se engaja em ações políticas para exigir Memória, Verdade e Justiça pelas violações cometidas durante a repressão. ${ }^{2}$ A partir de 2005, com a anulação das leis de anistia, abriram-se os caminhos legais para a responsabilização penal de agentes do Estado acusados de violações aos direitos humanos. Desde então, as narrativas sobre o passado de violência entraram definitivamente em cena (e em disputa) nos tribunais do país.

Com base em etnografia realizada em audiências dos chamados julgamentos de delitos de lesa humanidade na Argentina, problematizo como familiares de desaparecidos políticos, sobreviventes da repressão, atores judiciais e agentes do Estado acusados de violações, por meio das narrativas que enunciam, converteram os tribunais em lugar privilegiado para a afirmação de sentidos ao passado ditatorial: em disputa estão os projetos políticos, as palavras, as condutas e a moral de vítimas e acusados, assim como em questão estão a legitimidade dos julgamentos e a validade dos princípios jurídicos aplicados. O intuito é analisar como a cena judicial vem se desempenhando como espaço de luta para a produção do saber e da verdade sobre a ditadura na Argentina, ao passo que se apresenta como uma instância-chave para observar como são produzidos e confrontados os sentidos acerca do passado de violência.

Partindo do pressuposto de que o Direito constitui uma forma de ação política, proponho conduzir uma análise mais encantada da política e seu simbolismo, que considera a dimensão afetiva e existencial da ação humana - significados, emoções, o sagrado, moralidades (Verdery 1996, 1999). ${ }^{3}$ 
Ademais, pautando-me nas reflexões de Foucault (1996) sobre a relação entre a verdade e as formas jurídicas, analiso as narrativas (esses "fatos de discurso") que emergem na cena judicial "[...] como jogos, jogos estratégicos, de ação e reação, de pergunta e de resposta, de dominação e de esquiva, como também de luta" (Foucault 1996:9). ${ }^{4}$

Dessa forma, servindo-me das contribuições da antropologia para a análise das práticas jurídicas, volto-me à exploração dos problemas, processos e acontecimentos referentes aos conflitos protagonizados pelas leis, pelos tribunais e pelos grupos sociais que colocam suas demandam em termos de Justiça (Tiscornia \& Pita 2005). Procurando também desvendar o significado e os sentidos que o Direito cria e impõe, a ênfase da análise recairá na investigação da enunciação das leis e dos problemas que colocam, assim como das categorias do pensamento que pautam os procedimentos jurídicos (justiça, liberdade, direitos e legalidade), a fim de verificar como eles incidem na vida social.

Cabe destacar que no contexto das audiências judiciais etnografadas, as narrativas testemunhais, que se destinam à realização da Justiça, evocam memórias e histórias passadas, bem como demarcam categorias de acusação e de moralidades. Como corolário, a minha intenção neste artigo é demonstrar as dinâmicas entre representações sobre o passado ditatorial, entre agentes sociais (vítimas, acusados e atores judiciais) que produzem e se apropriam de representações e moralidades como parte de suas estratégias para a afirmação de memórias e verdades sobre a ditadura no espaço nacional argentino.

Proponho-me assim a refletir, seguindo Vianna (2005), sobre a linguagem moral que atravessa os direitos (que se expressa em expedientes de disputa e representação), buscando uma compreensão circunstanciada da moral como linguagem em uso - produção, veiculação e embate de significados - mas sobretudo como objeto de luta. Além disso, ainda no que se refere ao desenvolvimento de uma antropologia política da moralidade, são particularmente sugestivas as reflexões de Fassin $(2008,2013)$ para explorar como vítimas e acusados entendem ideológica e emocionalmente a distinção entre o bem e o mal, para analisar o sentido que palavras e atos têm para os agentes sociais, e para compreender a formação de sujeitos engajados em ações que são justificadas no terreno moral. 


\section{A demanda por justiça e responsabilização}

No vamos a negociar jamás una pena, una condena. Hace 12 años intentaron hacer la justicia transicional. Esto viene de Sudáfrica, que era que el torturador se siente junto al torturado para decir: "mira, me equivoqué, me dieron órdenes, te torturé, tenemos que olvidar". Esa es la justicia de amnistía, de perdón y que viene acompañada también de la reconciliación. Tampoco vamos a nos reconciliar. ¿Por qué tenemos que conciliarnos con el genocida y con el torturador? Que el torturador vaya a la cárcel, pague lo que tiene que pagar por este horror que cometió. Tiene que haber justicia. Y la justicia que decimos es cárcel común a todos los genocidas. La vida y la dignidad de nuestros hijos no se negocian. ${ }^{5}$

Desde o período de transição democrática, a luta por "Justiça" tornou-se um imperativo para as vítimas da ditadura militar argentina. Diante da dimensão que ganhara o tema dos milhares de detenidos-desaparecidos, o processo de transição política jamais pôde ser negociado pela via da reconciliação ou da anistia irrestrita. Cada vez mais o âmbito jurídico seria concebido como lugar de produção de Verdade, de sanção coletiva e de representação do passado. Mais do que uma aliança estratégica entre Estado e sociedade civil, dava-se então início a uma disputa pelo direito de controlar a esfera da lei e da memória (Das 1995).

Com o restabelecimento da democracia, o Estado empreenderia diversas ações para tratar o legado de violações. Sob a presidência de Raúl Alfonsín (1983-1989), seria criada a Comisión Nacional sobre la Desaparición de Personas (Conadep), cujo objetivo era reunir testemunhos, documentos e redigir um informe final relatando as violações cometidas durante a ditadura. ${ }^{6}$ Além disso, em 1985, ocorreram as audiências do emblemático julgamento conhecido como Juicio a las Juntas, que culminou na condenação dos membros das três primeiras Juntas Militares da ditadura. Pouco depois, também em tribunais civis, iniciaram-se processos contra oficiais que haviam atuado no I Corpo do Exército e na Escuela Mecánica de la Armada (ESMA). ${ }^{7}$ Nessas causas judiciais, a narrativa humanitária do Informe Nunca Más seria utilizada como estratégia central das acusações.

A definição da violência em termos de "violações aos direitos humanos" introduziu a dimensão jurídica no conflito político. Como ressalta Jelin (2008), o procedimento jurídico, com suas formalidades e ritualística, converteu "vítimas" em "testemunhas", "repressores" em "acusados", enquanto os juízes apresentavam-se como a única autoridade capaz de julgar com "neutralidade" os fatos do passado. Através da retórica supostamente neutra e abstrata do "Direito", a narrativa sobre a repressão parecia ganhar contornos mais objetivos e realistas. ${ }^{8}$ 
O alcance dos julgamentos, entretanto, seria limitado pela aprovação de duas leis de anistias nos anos 1986 e 1987 (Ley de Punto Final e Ley de Obediencia Debida): a primeira estabeleceu um prazo limite para a apresentação de novas acusações e para o processamento dos acusados, enquanto a segunda absolveu da responsabilidade penal todos aqueles que da patente de tenente-coronel para baixo haviam cometido violações. Com o início do mandato presidencial de Carlos Menem (1989-1999), seriam concedidos indultos a todos aqueles que respondiam a processos criminais e aos já condenados. ${ }^{9}$

Não obstante, o movimento de familiares de desaparecidos continuou reivindicando uma lei específica que reconhecesse a figura do detenido-desaparecido. Desde o princípio, os familiares recusaram-se a aceitar qualquer mecanismo legal que assimilasse os desaparecidos a outras figuras com estatuto jurídico já reconhecido. A demanda não se dirigia ao reconhecimento oficial da morte, mas sim do desaparecimento forçado de pessoas. Por conseguinte, seria sancionada, em 1994, a lei que criava a figura ausente por desaparición forzada.

Com essa medida, o Estado reconhecia oficialmente não apenas a condição (e a existência social) dos detenidos-desaparecidos, mas também de vítimas e familiares das vítimas, além do contexto que os originou (o terrorismo de Estado). Forjada para tratar o legado de violações da ditadura, essa taxonomia jurídica delimitou fronteiras entre grupos sociais, assim como critérios para o reconhecimento de direitos das víctima del terrorismo de Estado. Como analisa Vecchioli (2001 e 2005), os familiares de desaparecidos adquiririam então preeminência, ao passo que suas demandas, apresentadas em virtude dos direitos de sangue, impuseram-se a qualquer outro tipo de reivindicação. Para o sistema judicial argentino, somente os sobreviventes, os assassinados, os desaparecidos e seus familiares serão considerados afetados.

Tal processo demonstra a importância do Estado e do discurso jurídico na legitimação de identidades, categorias e representações, e revela o porquê de o campo jurídico constituir-se como um dos lugares privilegiados de luta para a afirmação das memórias sobre a ditadura. Através de atos legislativos (leis e regulamentações) nomeia-se o indivíduo, define-se o seu status legal, e são formulados os meios legítimos para a sua reparação, como coloca Das (1995). Se tais medidas podem resultar das mobilizações dos afetados, por outro lado, define-se como papel do Estado a responsabilidade de investigar, julgar e reparar os crimes.

Enquanto uma parte dos familiares de desaparecidos rejeitou a reparação econômica, outra parte daria seguimento aos processos penais 
individuais, aproveitando as fissuras legais deixadas pelas leis de anistia (estupro, apropriação de menores ${ }^{10}$ e apropriação extorsiva de bens). Além disso, visando questionar a validade das anistias, familiares empreenderam ações no plano transnacional a favor da aprovação de uma convenção sobre o desaparecimento forçado no âmbito da OEA e da ONU. Concomitantemente, pelo critério de nacionalidade das vítimas, apresentaram denúncias em tribunais de outros países, onde ocorreram julgamentos pelo desaparecimento de cidadãos estrangeiros em território argentino.

Cabe destacar que a Convenção Interamericana sobre Desaparecimentos Forçados incluiu inovações legais que tiveram implicações significativas para o processo de responsabilização penal na América Latina, como aponta Sikkink (2011). Na medida em que o desaparecimento forçado era categorizado como um delito de lesa humanidade e como um crime continuado (o delito não cessa até o aparecimento do corpo), ele deixava de estar sujeito às limitações prescricionais ou anistias.

Nessa luta deflagrada no campo do direito internacional, tribunais de outros países começariam a julgar repressores das ditaduras latino-americanas fora do critério de nacionalidade das vítimas, a exemplo da atuação do juiz espanhol Baltazar Garzón contra o ex-ditador chileno Augusto Pinochet, preso em Londres em 1998. A partir de então, o conceito de perseguição internacional de crimes de lesa humanidade e a doutrina da jurisdição universal ganhou força, sob o argumento de que "El territorio es el mundo, la nacionalidad universal y los intereses los de la humanidad" (Slepoy 2011:108).

Esse panorama global produziria efeitos legais e políticos importantes na Argentina, onde as demandas dos familiares de desaparecidos geravam significativa repercussão social. Com o crescente processo de reconhecimento dos convênios internacionais de direitos humanos, do princípio da preeminência do direito internacional sobre os direitos internos e do preceito da imprescritibilidade dos crimes de lesa humanidade, a exigência de anulação das anistias seria progressivamente incorporada. Mesmo sem alcançar os votos necessários para a sua total anulação, em março de 1998, o Congresso Nacional revogou as leis de anistia. Pouco depois, numa causa judicial conhecida como Causa Simón Julio, formulou-se o pedido de anulação das referidas leis, e juízes de tribunais de instrução de outras regiões do país seguiriam essa decisão.

Em agosto de 2003, o Congresso votou pela nulidade das leis de anistia. No mês seguinte, iniciaram-se novas causas judiciais, enquanto eram reabertas outras que haviam ficado interrompidas com as anistias (Causa ESMA e Causa I Cuerpo del Ejército), dando-se início à etapa de instrução 
dos julgamentos. ${ }^{11}$ Finalmente, em junho de 2005, a Corte Suprema de Justiça confirmaria a inconstitucionalidade das anistias, argumentando a sua incompatibilidade com a Constituição Nacional, com as obrigações internacionais assumidas pelo Estado, reiterando também a preeminência das normativas internacionais sobre as nacionais. Desse modo, a partir de 2006, deu-se seguimento à etapa oral e pública das primeiras causas que investigavam crimes cometidos durante a ditadura e multiplicaram-se os julgamentos em diversas regiões do país. ${ }^{12}$

Seriam, portanto, mais de vinte anos de luta dos familiares de desaparecidos pela realização de justiça, processo, conforme discutido, marcado por avanços e retrocessos. Considerando o conjunto de ações e a trajetória de luta por Memória, Verdade e Justiça do movimento de direitos humanos, processo que permitiria a instituição de uma verdade emblemática sobre a ditadura (Crenzel 2008), tais julgamentos se constituiriam em espaço-chave para observar como são produzidos e confrontados sentidos sobre o passado de repressão.

\section{Entre a Verdade Jurídica e a Verdade Histórica}

Abertos os caminhos para a responsabilização penal, o movimento de familiares de desaparecidos viu nos julgamentos orais e públicos uma oportunidade para a determinação da Verdade sobre a repressão. No presente nacional, a cena judicial vem se desempenhando como um dos locus centrais de produção e confrontação do saber e da verdade sobre a ditadura argentina, convertendo o campo jurídico em um importante espaço de luta pela afirmação de sentidos ao passado ditatorial.

Para os familiares das vítimas, a função simbólica dos julgamentos é atribuir um sentido ao sucedido. Agustín Cetrangollo, filho de desaparecido e militante de H.I.J.O.S., considera os julgamentos uma instância de reparação para familiares e sobreviventes. Ressalta também que os julgamentos dos genocidas funcionam como um instrumento para julgar o modelo político, econômico e social implantado pelos militares. Portanto, mais do que determinar a pena e o castigo, o ritual do julgamento penal cumpriria o papel de difundir valores à sociedade e de consolidar uma memória pública sobre a ditadura. Daí a importância de sua publicização e de respeitar o caráter público das audiências orais.

No decorrer das audiências, ao mesmo tempo em que o desaparecimento forçado ganha uma definição jurídica (crime de lesa humanidade), familiares, sobreviventes, procuradores e advogados buscam o reconhecimento social 
das vítimas do terrorismo de Estado. Por meio de seus testemunhos, procuram afirmar as identidades políticas dos desaparecidos - em contraposição ao que ocorreu durante o Julgamento das Juntas militares em 1985, quando as histórias de militância foram intencionalmente omitidas. Essa novidade se deve tanto a uma estratégia da acusação, como discutirei adiante, quanto a uma necessidade que familiares e sobreviventes têm de valorizar as suas próprias trajetórias políticas, como também as dos desaparecidos.

Vale salientar que a política que envolve a mobilização da figura dos desaparecidos é beneficiada por uma aura de santidade, que se presume que os mortos tenham, e pela ressacralização da ordem política que eles sustentaram, como sugere Verdery (1999). Tal sacralização aponta para uma qualidade particular dos mortos enquanto símbolos políticos: funciona como catalisador de emoções no campo político. A sua autorreferencialidade mobiliza afetos preexistentes, evoca sentimentos de perdas pessoais ou a identificação com aspectos específicos da biografia da pessoa morta. No caso dos detenidos-desaparecidos, essa qualidade é potencializada por uma trajetória que os associa à ideia de desaparecimento simbólico, sofrimento e vitimização.

Retomando as proposições de Durkheim (1972) sobre a relação entre a moral e os sentimentos, Vianna (2005) argumenta que, no contexto das audiências judiciais, o reconhecimento do sofrimento do outro como algo capaz de motivar ou justificar uma ação revela tanto a produção de uma leitura do sujeito sobre si mesmo (colocada em termos morais) quanto organiza as formas pelas quais esse ato deveria ser lido por outros. Os embates que ali se dão devem ser compreendidos então como enunciados socialmente demarcados pelo sentido moral das ações dos próprios agentes e daqueles com os quais estão postos em relação. Os sentimentos (raiva, frustração, angústia, tristeza, sofrimento), através de sua exposição e reflexão, constituem e compõem moralidades, funcionando como armas para disputas e afirmação de memórias e verdades.

Nos tribunais, as emoções cumprem assim um papel persuasivo e tático (Bailey 1993) na medida em que ajudam a legitimar aqueles que as expõem. A encenação das memórias e a dramatização pública do sofrimento privado no âmbito jurídico impõem à sociedade a necessidade de reconhecer as mentes e os corpos das vítimas, ao passo que coloca em debate a questão da culpa e da responsabilização (Das 1995). Desde que as sociedades contemporâneas investiram o poder judicial de autoridade para pronunciar a Verdade, os tribunais tornaram-se um espaço apropriado para essa encenação.

Segundo afirmam familiares e sobreviventes, seus testemunhos conformam um material valioso para a construção da memória. As sentenças 
judiciais atribuem legitimidade aos seus relatos, permitindo que sejam socialmente reconhecidos. Além disso, o espaço do tribunal vem se constituindo como lugar de homenagem às vítimas. Atos são organizados em frente aos tribunais, principalmente nos dias de início ou término dos julgamentos. Alguns familiares comparecem assiduamente às audiências, pois entendem ser uma forma de tornar os desaparecidos presentes e de agradecer a todos aqueles que aceitaram a dolorosa tarefa de prestar testemunho, como é o caso de Adela Antokoletz. Irmã de um desaparecido e filha de uma histórica Madre de Plaza de Mayo já falecida, ao longo de todo o debate oral da Causa ESMA, Adela comparecia vestindo um pañuelo sobre a cabeça e portando uma fotografia de seu irmão desaparecido. Segundo ela, esta era uma forma de homenagear os desaparecidos e a luta das Madres por Justiça.

As audiências judiciais funcionam, desta forma, como um ritual para a rememoração dos desaparecidos e para a valorização de suas identidades políticas. Na antessala, após longos anos, reencontros emocionados se produzem entre pessoas que compartilharam a militância política em anos ditatoriais. O público é integrado majoritariamente por familiares, sobreviventes, ativistas de direitos humanos e jornalistas. Tal como observou Arendt (2008a) em sua análise sobre o julgamento de Eichmann, a maior parte do público já conhece o que há para saber e não precisa daquele julgamento para tirar suas próprias conclusões sobre o que sucedeu no passado. Ainda assim, familiares e sobreviventes consideram o julgamento um ato simbólico de reparação por crimes que, a partir do momento em que foram definidos pelas normativas internacionais como de natureza imprescritível, parecem impor o ato de memória como dever.

Parece-me assim sugestivo analisar esses julgamentos como rituais; na medida em que se constituem como tipos específicos de eventos, mais formalizados, " [...] há uma ordem que os estrutura, um sentido de acontecimento cujo propósito é coletivo, e uma percepção de que eles são diferentes" (Peirano 2001:8). O drama do desaparecimento e da tortura é reencenado narrativamente ao longo do testemunho judicial, podendo ser assim analisado como ato performativo (Turner 1974, 1985) "com poder não apenas de argumentação, no sentido da organização racionalizada dessa memória e de seu uso para um objetivo concreto, mas também de trazer ritualmente à cena o já vivido, de modo que possa ser partilhado de forma alegórica também pelos demais presentes" (Vianna 2005:37). Logo, nesses "julgamentos-rituais", as disputas pelo reconhecimento de uma verdade jurídica sobre a ditadura revelam como o campo jurídico pode afetar as relações de poder e ampliar as práticas sociais de memória. 
Em 2007, desde que as leis de anistias foram anuladas, foi pronunciada a primeira sentença contra agentes do Estado responsáveis pelo desaparecimento de pessoas durante a ditadura. Nela, o juiz Carlos Rozanski definiu a repressão como um genocídio, decisão que foi considerada uma sentença histórica para o movimento de familiares, que celebrou o fato de o tribunal ter validado a sua própria interpretação sobre o que ocorrera em anos ditatoriais: um genocídio perpetrado por razões políticas. Produzia-se assim um efeito de verdade sobre uma memória em disputa, tendo em vista que nem todos os tribunais são coincidentes com tal categorização.

Cabe destacar que a questão de como tipificar o sucedido se deve menos a um problema de variação da pena - visto que os responsáveis já estão sendo condenados com a pena máxima permitida pelo ordenamento jurídico (prisão perpétua) - do que a intenção de afirmar juridicamente que tais delitos foram cometidos num marco social específico: o contexto dos massacres massivos e da utilização de uma tecnologia de poder na qual a "negação do outro" encontra o seu ponto limite (o desaparecimento físico e simbólico da pessoa). Ou melhor, a validação jurídica visa, sobretudo, conferir estatuto de verdade a uma determinada memória sobre o sucedido em anos ditatoriais.

Haveria assim da parte do movimento de familiares uma vontade de categorização (genocídio, terrorismo de Estado), que se articula no campo jurídico com a produção de um discurso de verdade. Por isso, diversos atores sociais (incluindo membros do corpo jurídico) encontram-se empenhados em introduzir a figura do genocídio nas resoluções judiciais relacionadas aos crimes da ditadura, trazendo para o âmbito judicial a referência ao genocídio argentino tal como já aparece na vida social.

Em face da restrição dos "grupos políticos" da jurisprudência internacional, alguns procuradores e advogados querelantes vêm procurando argumentar que na Argentina ditatorial o Estado teria praticado o aniquilamento sistemático de uma parte significativa do grupo nacional ${ }^{13}$ A repressão não teria ocorrido de maneira indiscriminada, mas se dirigiu a um grupo social previamente definido, integrado por indivíduos que, de alguma maneira, foram considerados um obstáculo para a implantação do projeto político-econômico pretendido pela ditadura. Assim o fez, por exemplo, a advogada Mirta Mantaras, em setembro de 2009, em sua alegação na Causa I Cuerpo del Ejército. O procurador Alejandro Alagia, que atuou na Causa $A B O,{ }^{14}$ também se posicionaria a favor dessa definição (genocídio), argumentando sobre a importância desses julgamentos para fomentar a luta pelo sentido e para a atribuição de um significado verdadeiro ao sucedido. 
Embora existam diferenças entre os argumentos das acusações, procuradores e advogados querelantes coincidem em caracterizar a repressão como um plano sistemático de tortura e extermínio, elaborado e executado pelo Estado contra um grupo social específico, definido segundo critérios políticos. Daí que uma das estratégias utilizadas atualmente pelas acusações seja explicitar a identidade política das vítimas para comprovar tal especificidade da repressão.

No dia 19 de outubro de 2010, no decorrer das alegações da acusação na Causa $A B O$, os advogados e o procurador expuseram as fotos dos desaparecidos que haviam sido objeto do processo, informando nome, profissão, data do sequestro, centro clandestino de detenção pelos quais passaram, destacando as organizações políticas nas quais haviam militado, momento traduzido em grande emoção para os familiares presentes. Também pediram às testemunhas que falassem sobre a sua história de militância (como também da dos desaparecidos), tanto para qualificar os fatos da repressão como um genocídio contra um "grupo político" quanto para defender os sobreviventes das perguntas dos advogados de defesa (que procuravam deslegitimá-los moralmente denunciando suas atividades terroristas). Argumentavam que a ditadura militar havia perpetrado um plano sistemático de extermínio contra seus inimigos, "uma geração de jovens militantes", com o objetivo "de implementar um plano econômico e reorganizar política, moral e culturalmente a nação". Uma das advogadas utilizou o termo massacres administrativos, cunhado por Arendt (2008a, 2008b) para se referir ao caráter rotineiro e burocrático do extermínio.

Enquanto entre o público circulavam panfletos com as fotos, os nomes e os codinomes dos acusados, a advogada escolhia alguns casos para descrever os procedimentos de sequestro e tortura. O procurador selecionou alguns testemunhos para discorrer sobre a tortura. Tipificou tais condutas aberrantes como crimes de lesa humanidade e enfatizou a continuidade delitiva do desaparecimento forçado (reiterando, com isso, a sua imprescritibilidade), mesmo argumento utilizado pelos procuradores Guillermo Friele e Felix Croux nas causas Automotores Orletti e Vesubio, respectivamente.

Ainda que as acusações busquem comprovar o caráter massivo dos crimes que são objeto desses processos penais, a responsabilização aparece de forma individualizada, e as causas são estruturadas pelo somatório de delitos individuais (privação ilegítima da liberdade, tortura, homicídio, estupro, apropriação de menores) contra pessoas particulares. Tendo isso em vista, alguns desses processos penais foram organizados por circuitos repressivos (a exemplo da Causa $A B O$ ), tanto para racionalizar os julgamentos (evitando a abertura de inúmeras causas individuais) quanto para evitar que as vítimas sejam convocadas a prestar infinitas declarações testemunhais. 
Por outro lado, a advogada e militante de H.I.J.O.S. Ana Oberlín destacaria a complexidade desses processos penais devido à quantidade de vítimas e acusados, à questão do "limite biológico" (acusados e testemunhas já falecidos ou com problemas de saúde), e à sua repercussão social. Existia ainda uma enorme dificuldade para reunir provas trinta anos depois de transcorridos os eventos. O objeto da investigação consiste justamente em um sistema clandestino de repressão, que se preocupou em manter suas operações ilegais da forma mais secreta possível, dispondo para tanto de uma série de mecanismos para assegurar a impunidade - vedação das vítimas, utilização de codinomes por parte dos repressores, destruição e ocultamento de corpos, locais de detenção, arquivos e documentação.

Por isso, tem força nesses processos a importância dos "arquivos vivos". São as memórias de familiares e sobreviventes que se constituem como a principal prova para a demonstração de crimes cometidos na mais absoluta clandestinidade. Procuradores e advogados querelantes buscam salientar essa particularidade e, ao alegarem sobre a dificuldade de recoleção de evidências materiais, pedem aos juízes especial consideração pelos testemunhos das vítimas e seu reconhecimento como provas criminais legítimas. Procuram ainda incorporar ao processo todo tipo de prova: arquivos da Conadep, livros de autocrítica de membros das forças repressivas, testemunhos, material de imprensa e, quando possível, o próprio corpo delito (em especial os restos dos desaparecidos identificados) - como o fizeram as acusações na Causa I Cuerpo del Ejército, Causa ABO e Causa ESMA.

Em suma, o que parece se colocar nesses julgamentos tão particulares é a possibilidade de determinar a verdade jurídica em condições não convencionais de exercício das regras da prova. São os testemunhos daqueles considerados capazes de saber - seja por sua sabedoria (testemunhas de conceito), seja por terem presenciado o acontecimento (testemunhas presenciais) - que permitem determinar se algo realmente aconteceu. Ao se converter num procedimento legítimo de autenticação e de transmissão da verdade, o inquérito constitui-se como uma forma política de exercício do poder (Foucault 1996). Ou melhor, nos julgamentos de delitos de lesa humanidade a enunciação da verdade deriva sobretudo de um conhecimento de ordem retrospectiva, pautado no testemunho, um saber produzido por meio do inquérito e da lembrança, revelando o peso da memória das vítimas no processo de construção da verdade jurídica. Suas memórias sustentam a prática jurídica, ao passo que produzem o saber sobre a ditadura. E se as audiências orais levam à ritualização do sucedido - através das narrativas daqueles que sabem ou viveram "em carne própria" - o tribunal transforma-se em espaço não apenas para a afirmação da verdade, mas também para o seu questionamento. 


\section{Por "Memória, Verdade e Justiça": testemunhos de sobreviventes}

Como na tragédia de Édipo-Rei, a ideia de que a testemunha, mediante a enunciação da verdade, pode vencer os poderosos e de que o povo, através do processo, conquista o direito de julgar quem o governa (Foucault 1996) parece estar no centro das considerações das vítimas da ditadura argentina. $\mathrm{O}$ ato de testemunhar e de exigir Justiça colocou-se como um dever, quando em tempos ditatoriais familiares de desaparecidos saíram a denunciar os sequestros e sobreviventes apareceram para narrar, em primeira pessoa, a experiência do horror vivida nos centros clandestinos de detenção.

Como salienta Agamben (2008), se mártir é a palavra grega para testemunha, termo que deriva do verbo recordar, a vocação do sobrevivente não pode ser outra senão a da memória. Enquanto alguns se calam diante de uma lembrança que sentem como insuportável, outros percebem no encarceramento o centro de suas vidas, pois se consideram testemunhas de algo que os desautoriza a esquecer e a silenciar (Levi 1990).

Para muitos aparecidos-sobreviventes e familiares de desaparecidos da ditadura argentina, a memória converteu-se em um bem e em um dever, ao passo que se lhes apresenta como uma necessidade jurídica, moral e política (Sarlo 2007). Se as autoridades militares ocultavam ou negavam o ocorrido, as narrativas dos afetados impuseram-se como a matéria-prima para a construção da memória sobre o passado. Passadas décadas de lutas pela memória, seus testemunhos conformam a base das provas dos julgamentos e servem de fundamento para a determinação da verdade jurídica sobre a ditadura. Alguns se apresentam como parte querelante e se dirigem espontaneamente ao tribunal, pois fizeram do testemunho um compromisso existencial e político. Outros comparecem receosos, com medo de sofrerem represálias ou de verem suas condutas passadas submetidas a julgamento moral.

Graciela Daleo, sobrevivente da ESMA, ex-militante da organização Montoneros, ${ }^{15}$ vem testemunhando desde os anos 1980. Afirma que a sua sobrevivência se traduziu no compromisso de narrar o que viveu e defende a necessidade de reconhecer o lugar simbólico das condenações penais, assim como do Direito como um espaço de luta política. Em seus testemunhos, empenha-se em desconstruir o estigma que, ainda hoje, pesa sobre os sobreviventes dos centros clandestinos de detenção.

[...] si estás vivo por algo será...; si contás el horror, lo multiplicás, si te lo callás, ¿qué sos?, "un servicio" ¿̇por qué no lo decís?, y además estás quitando la posibilidad de la construcción de la verdad y la lucha por la justicia. [...] todas estas cosas confluyen en la cuestión de que el campo de concentración era la muerte, de allí sólo podía salir la muerte, o sea, nadie (Daleo 2001:109). 
Cabe salientar que uma das vozes mais negadas durante as décadas de 1980 e 1990 na Argentina era a dos sobreviventes. Em contraposição à heroicidade e à inocência atribuídas aos detenidos-desaparecidos que nunca regressaram, sobre a minoria de aparecidos-sobreviventes recaiu o estigma de colaboradores, delatores, cúmplices ou traidores, processo atrelado à confusão de papéis entre vítimas e algozes dentro dos centros clandestinos de detenção. Junto ao sentimento de culpa pela sobrevivência (por algo terá sobrevivido), aos aparecidos restou o silêncio. Enquanto os familiares podiam narrar o que sucedera, aos sobreviventes só lhes era permitido relatar as vexações corporais sofridas durante o cativeiro. Como forma de proteger o lugar de vítima tão penosamente conquistado, não havia escuta possível para qualquer referência às suas trajetórias de militância (como também não havia para os detenidos-desaparecidos). Foi somente no final da década de 1990 que os sobreviventes começaram a aparecer, expondo outras narrativas sobre o passado e afirmando o seu lugar como representantes de uma geração e de um projeto político alvo da repressão.

A questão do colaboracionismo e da culpa revela-se como um tema clássico da literatura sobre os sobreviventes do Holocausto, como lembra Agamben (2008). Primo Levi (1990) refletiu de maneira primorosa sobre a questão, afirmando que essa "zona cinzenta", habitada pelos "prisioneiros privilegiados" ou "prisioneiros-funcionários", teria sido suficiente para "confundir a necessidade dos internos de julgar", ao passo que era demonstrativa do processo de "perda de autonomia" do povo judeu, como ironizou Arendt (2008a).

Alguns aparecidos procuram inverter esse processo de transferência da culpa dos perpetradores para as vítimas. Ao mesmo tempo em que narram sobre o trato desumano que receberam no cativeiro, querem demonstrar como jamais estiveram em condição de decidir (nem mesmo sobre a própria vida ou morte). E se foram propositalmente alocados nessa zona cinzenta da sobrevivência foi para gerar suspeitas, propagar o terror ${ }^{16}$ e impedir qualquer solidariedade entre os sequestrados: “[...] comprometê-los é carregá-los de crimes, manchá-los de sangue, expô-los tanto quanto possível: assim contraem com os mandantes o vínculo da cumplicidade e não mais podem voltar atrás" (Levi 1990:21). Apesar de acusados e constantemente forçados a justificar-se, são os sobreviventes que podem melhor contribuir para a reconstrução da face mais secreta da repressão. Nas audiências judiciais, eles se esforçam para transmitir o que viram e viveram nos centros clandestinos, mas também para conferir legitimidade às suas narrativas.

No dia 15 de outubro de 2010, no âmbito da Causa ESMA, madres portando seus lenços sobre as cabeças e demais familiares carregando broches 
com as fotografias de seus desaparecidos se sentaram na primeira fileira destinada ao público para escutar o testemunho da sobrevivente María Milesi, que iniciou o seu relato identificando-se como uma ex-militante da Juventud Peronista. Ela então contou sobre a sua condição física e psíquica durante o cativeiro, sobretudo quando viu seu filho (que tinha apenas quatro meses de vida) ser levado para uma das sessões de tortura, momento de seu testemunho em que, visivelmente emocionada, perdeu a fala. Disse que permaneceu isolada, vendada e algemada durante meses, até ser levada para trabalhar no subsolo da ESMA, onde cumpriria com muita culpa a tarefa de falsificar documentos. Procurando culpabilizá-la pela sobrevivência, os advogados de defesa questionaram se ela saberia explicar por que havia sido liberada ou levada para trabalhar no escritório de falsificação. María respondeu, enfaticamente e indignada, que não existia "nenhuma lógica" naquele lugar e que a intenção era "enlouquecer, quebrar e romper com qualquer laço de confiança entre os prisioneiros".

Vale aqui relevar, seguindo Pollak (2006), as particularidades do testemunho no âmbito judicial. Trata-se, em primeiro lugar, de um protocolo formalizado (número de ata, número do processo, data e hora de chegada da testemunha, seu nome, data de nascimento, profissão etc.). Em segundo lugar, esses testemunhos somente podem acontecer após a clássica fórmula jurídica a testemunha jura que as declarações ditas correspondem à verdade. A testemunha está, portanto, sujeita a penalizações.

Em uma das audiências da Causa ESMA, em outubro de 2010, a sobrevivente María Adela Pastor foi lembrada pelo tribunal de que poderia ser penalizada em até dez anos de prisão caso mentisse. Ela também se viu obrigada a responder se tinha algum interesse especial nas pessoas que eram parte do processo (vítimas ou acusados). Após esse constrangimento inicial, foi submetida a um longo interrogatório sobre as suas condições e de seu companheiro (ainda desaparecido) durante o cativeiro. De olhos fechados, rememorou as sensações de terror experimentadas na ESMA. Ao final de sua declaração, fez questão de afirmar que tinha sido uma "militante popular peronista" e que se sentia orgulhosa de ter "lutado por justiça social e liberdade", momento em que o público conteve os aplausos, oportunamente lembrados pelo tribunal de sua proibição. Na saída, com lágrimas nos olhos, María recebeu abraços, agradecimentos e cumprimentos emocionados por parte dos familiares presentes.

No contexto do tribunal, o testemunho deve transformar-se na evidência de um crime. As declarações levam assim a marca dos princípios da administração da prova jurídica: limitação ao objeto do processo, eliminação de elementos considerados externos, de modo que se possa oferecer uma 
perspectiva justa e verdadeira sobre a realidade, como analisa Pollak (2006). O depoente deve conter suas emoções (mesmo diante das narrações mais dolorosas e privadas), ao passo que vê a sua memória e legitimidade como testemunha sob constante questionamento (sobretudo os sobreviventes, considerados testemunhas suspeitas e politicamente interessadas).

Durante as audiências das Causas $A B O$ e ESMA, não apenas advogados defensores, mas também o público composto por familiares e sobreviventes colocaria em questão a credibilidade e a moral das testemunhas que, a depender de seu depoimento ou prestígio como militantes de direitos humanos e vítimas exemplares, se tornavam mais ou menos críveis. Em audiência da Causa ESMA, em 14 de outubro de 2010, o padre Gabriel Bossini foi chamado a testemunhar sobre a sua prisão junto com um grupo de pessoas ainda desaparecidas. À medida que seu relato se desenvolvia sem que pudesse agregar nenhuma informação, afirmando que fora confundido com um padre guerrilheiro, que não sofrera agressão e salientando seu desacordo com membros da Igreja vinculados à Teologia da Libertação, o público de familiares e ativistas expressava indignação, acusando-o de colaborador da ditadura, ao passo que os advogados querelantes alegavam que a testemunha estaria omitindo a Verdade.

Já as defesas, além de demandarem a apresentação de evidências materiais, exigiam dos sobreviventes que diferenciassem os fatos que haviam presenciado daqueles que haviam reconstruído através de fontes ou narrações alheias. Exigir que as testemunhas não tivessem conversado entre si ou que suas memórias não tivessem sofrido com a influência do tempo e dos relatos que leram e escutaram - como procuraram alegar as defesas na Causa $A B O$ - seria como decretar a impossibilidade desses julgamentos.

Passados mais de trinta anos dos eventos que são objeto desses processos penais, as vítimas se organizaram em coletivos para produzir informação; registraram e publicaram suas memórias, e se dispuseram a todo tipo de suporte que pudesse comportar essas memórias. Além disso, dificilmente suas declarações poderiam se limitar ao objeto dos processos ou gozar da devida isenção política, como estabelece a norma jurídica. Enquanto as audiências (através do ato de testemunhar) são concebidas como uma "instância de reparação" para familiares e sobreviventes, torna-se inevitável que as vítimas não transformem o seu dia de Corte numa ocasião para colocar (publicamente e diante dos acusados) suas considerações sobre a política ou para afirmar não puderam nos quebrar, não nos derrotaram.

Se em 1985, no decorrer do Julgamento das Juntas Militares, os sobreviventes precisaram ocultar suas identidades políticas ou explicar por que haviam sido sequestrados (e também sobrevivido), a partir de 2005, os 
tribunais converteram-se em espaço privilegiado para a afirmação de suas militâncias. Em contraposição ao que ocorreu nos anos 1980 - quando os sobreviventes estavam sujeitos ao processamento penal por ações terroristas, recaindo sobre eles o estigma de colaboradores - atualmente se reconhece, em grande medida, o seu lugar como militantes de uma causa justa e a importância de seus relatos para a construção da memória.

Cabe então problematizar as condições que tornam possível o testemunho, assim como revelar as coações estruturais que estão na origem do silêncio (Pollak 1989, 2006). Os testemunhos das vítimas traduzem a sua vontade de tornar pública a palavra, ao passo que revelam um contexto que as autoriza a expressar suas militâncias por meio de narrativas centradas em certos personagens e acontecimentos. Suas memórias se veem, desta forma, dotadas de uma esfera de interesse ampliada, que varia de acordo com a notoriedade da pessoa e da sua valorização enquanto testemunha legítima e impoluta. Tal processo põe ainda em evidência um contexto de grande desprestígio daqueles que participaram da repressão ou que procuram justificá-la.

Nas audiências, algumas vítimas são consideradas testemunhas exemplares, tais como familiares de desaparecidos (sobretudo mães e filhas ou filhos) e sobreviventes que puderam alcançar um observatório privilegiado dentro dos centros clandestinos (sem que perdessem seu atributo de vítima impoluta). Principalmente os testemunhos daqueles que foram destacados militantes políticos e familiares que se tornaram referentes na luta pelos direitos humanos gozam de um interesse especial, não só porque dispõem de ferramentas para interpretar politicamente o que viram, mas também porque (como ex-combatentes) veem no testemunho um ato de guerra contra o fascismo e a injustiça, a favor da memória.

Assim ocorreu durante a declaração de Jaime Dri, sobrevivente da ESMA e um conhecido militante da organização Montoneros. A sua notoriedade se deve tanto ao fato de ser o único sequestrado da ESMA que conseguiu fugir (e sobreviver à fuga) quanto ao fato de sua história ter se transformado num célebre romance de testemunho do contexto pós-ditatorial argentino. ${ }^{17}$ Dri veio especialmente do México (país onde reside desde que se exilou) para fazer sua declaração na Causa ESMA em 16 de dezembro de 2010, num dia em que o público era visivelmente mais numeroso do que o habitual. Ele encerrou o seu testemunho demandando a Verdade sobre o destino dos detenidos-desaparecidos e proferindo um discurso inflamado sobre o papel da juventude no proceso político de liberación.

Fica patente como a política ocupa o centro das considerações nesses julgamentos. O conflito político passado - conflito que se impunha pautado na 
disputa entre projetos de nação antagônicos (socialismo x capitalismo), numa conjuntura marcada pela bipolarização da Guerra Fria, quando a política se apresentava como um campo social cindido entre direita e esquerda - se vê reatualizado e ritualizado nos tribunais por meio das memórias daqueles que se enfrentaram em tempos ditatoriais. Enquanto sobreviventes e familiares de desaparecidos buscam destacar a qualidade moral das vítimas do terrorismo de Estado (jovens militantes populares que lutaram por um projeto de país com mais justiça social) e afirmar um sentido ao sucedido (genocídio por razóes políticas, terrorismo de Estado), os imputados também usam o seu dia de Corte para reivindicar uma Memória Completa e ressaltar o valor de seus combatentes nessa guerra travada pelo bem maior da nação. Desta forma, os réus buscam oferecer uma memória alternativa sobre a ditadura, justificar suas ações, e colocam em questão os processos penais em curso.

\section{Por uma "Memória Completa" : a narrativa militar}

Há tempos as autoridades militares vêm se servindo de duas categorias, que desempenham papel preeminente na jurisprudência dos julgamentos de criminosos de guerra, para justificar a repressão ditatorial. Seriam elas as noções de Atos de Estado e Atos por Ordens Superiores. Como coloca Arendt (2008b), a noção de Atos de Estado fundamenta-se na proposição de que, em circunstâncias extraordinárias, governos soberanos podem ser forçados a fazer uso de meios criminosos diante de uma situação na qual a sua sobrevivência se vê ameaçada (seria o equivalente ao crime que o indivíduo comete em legítima defesa).

Desde os anos 1980, os militares argentinos apelaram para o argumento do mal menor ou do mal necessário para defender o atuado. Entre dois males (baixas na população civil ou a vitória da subversão), coube ao Estado optar pelo mal menor para derrotar a subversão e garantir o futuro da nação. Os implicados na repressão discorrem sobre suas ações atrelando a noção de Atos de Estado a um discurso que afirma a existência de uma guerra travada contra o inimigo subversivo, considerado uma ameaça à continuidade do verdadeiro ser nacional. Nas narrativas castrenses, a ditadura é então definida em termos de guerra antissubversiva, luta contra a subversão/terrorismo, guerra não convencional, guerra antirrevolucionária, guerra fratricida, guerra interna. Desta forma, pautados numa retórica que combina o discurso da guerra à dicotomia amigo-inimigo, os militares procuram reivindicar o atuado e justificar a repressão. 
O capitão da Marinha Jorge Acosta, no contexto de sua alegação na Causa ESMA, em outubro de 2011, usou de seu direito à defesa para afirmar publicamente uma versão alternativa sobre o passado. Recorrendo aos escritos de organizações armadas e aos testemunhos das vítimas durante o julgamento, ele se apresentou como um combatente de uma guerra interna travada contra o beligerante inimigo subversivo. Afinado com o projeto político do "Processo de Reorganização Nacional", como foi autoproclamada a ditadura, orgulhava-se de ter participado de uma guerra levada a cabo pelo bem da nação, mas também em nome de Deus e da filosofia ocidental e cristã contra o ateísmo marxista. ${ }^{18}$

Em dezembro de 2010, no dia do pronunciamento da sentença de um julgamento em Córdoba, o ex-ditador Jorge Rafael Videla também fez uso de seu direito à palavra para reivindicar o atuado. Videla defendeu a legalidade do emprego das Forças Armadas para combater e exterminar o terrorismo subversivo no marco de uma guerra interna iniciada pelas organizações terroristas. Segundo ele, o atuado estaria previsto legalmente no "Plano de Capacidades Internas" e no Código de Justiça Militar. Para o ex-ditador, tratou-se de uma guerra justa em defesa da Pátria, porém uma guerra irregular cujo signo distintivo teria sido a imprecisão. Nessa mesma ocasião, Videla assumiu suas responsabilidades castrenses e defendeu, diante do povo argentino e das Forças Armadas, a honra da vitória na guerra interna. Disse ainda lamentar as mortes, as sequelas que deixam toda guerra e deplorar a especulação do sofrimento alheio através do uso escuso de alguns da bandeira dos Direitos Humanos. ${ }^{19}$

Como demonstram as alegações de Videla, uma parte da corporação militar não nega que seus quadros possam ter sido responsáveis por atos atrozes durante a repressão, mas os justificam como sequelas, erros, excessos, imprecisão ou equívocos (fatos supostamente inevitáveis às guerras) cometidos no contexto de uma ação legítima. Os militares não foram sádicos ou criminosos, tal como as vítimas e a acusação procuram afirmar nos tribunais (e fora deles), mas oficiais empenhados numa ação histórica e grandiosa em nome da nação argentina.

Enquanto os implicados na repressão se voltam para o argumento de Atos de Estado e da guerra e suas sequelas para justificar o atuado, também recorrem à noção de Atos por Ordens Superiores. Videla alegou a inocência de seus subordinados, militares que teriam se limitado a cumprir ordens ajustadas à Doutrina então vigente, argumento repetido inúmeras vezes pelos próprios oficiais subalternos nas audiências judiciais: como bons e fiéis soldados, cumpriram as ordens que lhes haviam sido determinadas por seus superiores e pelas normativas de então (Constituição Nacional e regulamentos militares), embora admitam a dificuldade de tirar conclusões válidas sobre a legalidade ou a ilegalidade dos procedimentos. ${ }^{20}$ 
Ao mesmo tempo em que o argumento de Atos de Estado, Atos por Ordens Superiores e a retórica da guerra e seus excessos serve de fundamento para as defesas, os imputados procuram questionar a Memória difundida pelo movimento de direitos humanos. No âmbito da Causa ESMA, em outubro de 2011, o célebre capitão da Marinha Alfredo Astiz afirmou que as sequelas da guerra haviam sido ressuscitadas pelos ilegítimos querelantes, pelo governo Kirchner e por grupos fundamentalistas movidos por ódio, ressentimento, intolerância e vingança. ${ }^{21}$ Jorge Acosta denunciou a presença dessa memória cega, aglutinante e parcial que, segundo ele, fomentaria a divisão e a desunião da Pátria. Se antes seus inimigos foram terroristas subversivos, hoje seriam o governo nacional e os ativistas de direitos humanos, grupos que estariam empenhados numa ofensiva contra as Forças Armadas, promovendo uma campanha revanchista motivada pelo ódio e pela vingança. Se antes a guerra foi travada no campo militar, atualmente a guerra estava sendo deflagrada no campo psicológico através dos direitos humanos, da justiça, da educação, da cultura e da memória.

Videla também afirmou a derrota no campo político-ideológico. Segundo ele, os militantes teriam se mimetizado na sociedade como paladinos da defesa dos direitos humanos a fim de instaurar um regime marxista que prescreve a Constituição Nacional, Constituição que, de acordo com ele, guarda luto pela República desaparecida. O ex-ditador definiu a si mesmo como um preso político e aos julgamentos de delitos de lesa humanidade como uma situação de terrorismo judicial. Encerrou a sua fala dizendo que não pretendia alegar a sua defesa, mas aceitar aquela injusta condenação como mais um ato a serviço de Deus, da Pátria e da Concórdia Nacional.

Para os acusados, o enfrentamento passado entre a conspiração marxista subversiva e as Forças Armadas se converteu, no presente, numa batalha entre os deformadores da Verdade e aqueles que pretendem desmascará-los. Por isso, decidiram oferecer à sociedade uma Memória Completa. E se dentro dos tribunais alguns réus fazem uso de seu direito à palavra para expor a sua própria interpretação sobre o sucedido, nas ruas, as associações que reúnem familiares das vítimas do terrorismo/da subversão também procuram tornar legítima a sua memória sobre a ditadura.

A AFyAPPA e a AfaVitA ${ }^{22}$ - coletivos liderados por mulheres (em geral, esposas de agentes do Estado implicados na repressão) - clamam pelo reconhecimento de outras vítimas por razões políticas que não as do terrorismo de Estado: as vítimas da violência cometida pela guerrilha ou pelo terrorismo subversivo. Com os lemas Memória Completa e Justiça Completa, denunciam as ações das organizações armadas (esto también pasó), pedem igualdade perante a Lei (para ellos no existen los derechos humanos), demandam que 
os crimes da guerrilha sejam categorizados como delitos de lesa humanidade, e exigem o direito à reparação econômica. Reivindicam ainda o estatuto de presos políticos para seus familiares processados pela Justiça, falam em terrorismo jurídico e mortos em cativeiro (em referência aos militares que faleceram respondendo a processo) e questionam a legitimidade dos julgamentos. Consideram-se vítimas de uma Justiça que, segundo elas, ignora os fundamentos da legalidade e que se guia por um poder escuso conduzido em nome dos direitos humanos. Clamam pela construção de uma Memória Completa e por um Nunca Mais livre de perspectivas ideológicas para que as vítimas da guerrilha possam ser incluídas no relato oficial sobre o passado. ${ }^{23}$

Como analisa Salvi $(2008,2010)$, tais grupos têm uma retórica e uma performance semelhantes à utilizada (e consagrada) pelas organizações de familiares de desaparecidos. Além de mobilizarem a figura da vítima, apelam aos laços de parentesco, às metáforas de sangue (la sangre derramada por el terror) e às narrativas do sofrimento e do luto. Invertendo o repertório político dos familiares de desaparecidos e forjando uma memória especular e reativa, estes outros familiares se dizem portadores de uma verdade silenciada e empenham-se na luta contra a deformação, a manipulação e a propaganda.

Enquanto fora dos tribunais esses grupos questionam a legitimidade dos processos penais, dentro deles os réus procuram atacar a legalidade dos procedimentos jurídicos aplicados. Alegam ter seus direitos desrespeitados por serem condenados por crimes que não estariam previstos no código penal no momento dos fatos (violação do princípio de retroatividade da lei), ou porque continuam detidos quando não poderiam mais estar (pela idade avançada ou pelo prazo de prisão preventiva expirado), conforme argumentou o capitão Acosta na Causa ESMA.

Alfredo Astiz também apelou para diversos qualificativos para definir o julgamento - falso julgamento, ato ilegítimo, simulação/paródia de julgamento - e questionou indignado o papel desempenhado pela ilegítima procuradoria, ressaltando que, como ato de protesto, preferia prescindir de seu direito à defesa. Videla também renunciou ao seu direito à defesa, argumentando que concluíra ser mais produtivo que seus advogados se dedicassem a deixar registrado para a história todas as irregularidades cometidas nesses julgamentos, que mais lhe pareciam um circo, uma paródia de julgamento sem justiça e sem direito.

Além de colocar em questão a legalidade dos julgamentos, alguns acusados e suas defesas indagam sobre a moral das vítimas-testemunhas, atacando o seu valor probatório (estão politicamente comprometidas) e alegando inconsistência das provas criminais. Por isso a insistência das defesas em revelar as identidades políticas das vítimas (eram todos guerrilheiros). 
Logo, se os sobreviventes e os familiares de desaparecidos conformaram um amplo repertório para se referirem aos acusados (genocidas, perpetradores, assassinos, torturadores, nazistas, fascistas, psicopatas, covardes, imorais, pervertidos), os réus também procuram desqualificar as vítimas, acusando-as de subversivos, terroristas, delinquentes-subversivos.

Durante a sua alegação na Causa ESMA, Alfredo Astiz ressaltou com raiva e indignação que os ilegítimos querelantes haviam apelado de forma desnecessária ao projetar as fotografias de crianças dos terroristas para causar um efeito emocional. Salientou ainda serem absurdas as afirmações de que os terroristas eram juventude militante e idealista, que lutaram por uma sociedade mais igualitária. Astiz mencionou crimes da guerrilha a fim de tornar verossímil o argumento da guerra, para questionar moralmente o lugar de vítima ocupado pelos ex-terroristas, bem como para desacreditar seus falsos e imaginários testemunhos. Jorge Acosta apelou para o tema do colaboracionismo, colocando em dúvida a identidade dos sobreviventes como agentes de inteligência da Marinha, afirmação que causaria consternação entre os familiares e os sobreviventes presentes. Para Acosta, as testemunhas necessárias eram antes de tudo portadoras de relatos falsos e mentirosos, e as acusações representavam uma grande falácia forjada a partir das narrativas de ex-terroristas. Ainda assim, guiado por suas convicções de cristão apostólico romano, considerava-se no dever de enunciar naquele tribunal a sua própria verdade, com minúscula.

Submetidos à condenação penal e moral, não resta alternativa aos acusados a não ser apresentar outra versão sobre o sucedido. O dever de testemunhar se expressa então como uma oportunidade para afirmar outra Verdade a fim de que a História possa um dia restituí-los ao seu devido lugar: serão lembrados como "soldados que lutaram para salvar a nação do terrorismo". Pouco antes de seu falecimento e como um dos representantes mais emblemáticos da ditadura, Jorge Rafael Videla parecia haver tomado para si essa obrigação. Em suas últimas declarações, o ex-ditador esboçou alguma crítica à repressão, mas ela não se dirigia propriamente ao atuado. No plano militar, Videla continuava afirmando-se vitorioso: aniquilaram a subversão e reorganizaram a nação. A crítica se referia ao que denominou de sequelas, erros da guerra contra a subversão, ou de derrota no plano político. Entre as sequelas estariam as condenações e as críticas sociais às Forças Armadas e o tema dos detenidos-desaparecidos.

Como Videla, outros acusados se sentem politicamente derrotados, mas não arrependidos. Tampouco se sentem culpados moralmente, apenas o foram penalmente. E se nos anos 1980 prevaleceu um discurso de teor negacionista (não há desaparecidos), no decorrer da história das lutas 
pelas memórias da ditadura na Argentina, e diante do crescente processo de legitimação das vozes dos afetados, os militares se veem impelidos a ressignificar suas narrativas sobre a repressão a fim de que ainda possam ter algum sentido social.

\section{Considerações finais}

Las víctimas y los victimarios, somos parte de una misma humanidad, colegas en un mismo esfuerzo por demostrar la existencia de las ideologías, los sentimientos, los heroísmos, las religiones, las obsesiones (Timerman 2000:132).

As narrativas sobre a repressão enunciadas nos julgamentos de delitos de lesa humanidade colocam em tela como o âmbito jurídico encontra-se, no contexto argentino, integrado ao campo de luta pela afirmação de sentidos ao passado ditatorial. Para as vítimas, esses julgamentos representam uma resposta do Estado às suas históricas demandas por Memória, Verdade e Justiça. Ao mesmo tempo em que reconhecem o lugar simbólico das condenações penais como instância de reparação, de difusão de valores, de reconhecimento e homenagem às vítimas, bem como de consolidação de uma Verdade e de uma memória pública sobre a ditadura, a demanda por Justiça dirige-se também à condenação moral das violações e dos perpetradores, exigência que se expressa no lema de H.I.J.O.S.: "Los Juzga un Tribunal, Los Condenamos Todos!". Logo, mais do que a validação da verdade de seus testemunhos no âmbito jurídico, também têm importância " [...] as motivações e as justificações: por que você fez isso? Você se dava conta de que cometia um delito?" (Levi 1990:11). A questão moral colocada refere-se à função do juízo humano (Arendt 2008a).

Como aponta Agamben (2008), as categorias jurídicas estão carregadas de sentido moral e religioso: culpa, responsabilidade, inocência, julgamento, absolvição. Por isso, nos julgamentos de delitos de lesa humanidade na Argentina ganha relevo a existência de um embate entre moralidades, embate que coloca em questão tanto as intenções e as condições nas quais tais atos foram realizados (atos traduzidos em termos de violações dos direitos humanos) quanto evidenciam as divergências entre as medidas legais adotadas nesses processos judiciais e outra ordem de regulações (os regulamentos e a doutrina militar vigente durante os anos ditatoriais, por exemplo).

Ancorada nas reflexões propostas por uma antropologia política da moralidade (Fassin 2008, 2013), neste artigo analisei como a Verdade é construída para cada uma das partes implicadas nesses julgamentos, bem 
como o lugar que ocupam os sentimentos na produção dessa Verdade. Buscou-se problematizar como vítimas e acusados entendem ideológica e emocionalmente a distinção entre o bem e o mal, desvendando os sentidos que palavras e atos possuem para os agentes sociais. Nas audiências judiciais ficou patente como a expressão das emoções (ressentimento, rancor, amargura, raiva, frustração e indignação) emerge como resposta a situações que são experimentadas e vividas pelos distintos atores sociais como uma injúria ou uma injustiça.

O ressentimento experimentado pelas vítimas se expressa como uma reação a um passado de violência. Elas não desejam vingança, mas demandam reconhecimento e "Justiça", enquanto se recusam a esquecer e perdoar: "¿Por qué tenemos que conciliarnos con el genocida y con el torturador? Tiene que haber justicia. Y la justicia que decimos es cárcel común a todos los genocidas", como afirmou a madre Nora Cortiñas. Em contraposição aos que defendem que o passado deve ser deixado para trás, para as vítimas a memória cumpre a função de tornar o crime uma realidade moral. O imperativo de Memória, Verdade e Justiça representa então uma forma de resistência, sobretudo quando o esquecimento e a reconciliação parecem consensuais - a anistia e a expiação como paradigmas universais e a empatia e o perdão como virtudes pessoais (Fassin 2013). Para familiares e sobreviventes, aceitar esse consenso implicaria abandonar potenciais procedimentos legais, além de supor a possibilidade unilateral de perdão (já que a maior parte dos acusados não expressa sinais de arrependimento). Portanto, o que as vítimas demandam é a Verdade sobre as circunstâncias e as razões da morte de seus familiares, uma justa retribuição aos criminosos, além da defesa de uma forma específica de dignidade: "La vida y la dignidad de nuestros hijos no se negocian".

Já os acusados ressentem-se diante de uma situação na qual a sua posição social (agentes do Estado que atuaram na repressão) gera frustração e repúdio social. Os réus expressam o seu descontentamento com a política de Memória, Verdade e Justiça posta em marcha, incitando a sua animosidade e rancor contra certos segmentos da população (movimento de direitos humanos, governo nacional, membros do Judiciário). O dilema moral que enfrentam, por terem feito uso de meios escusos para derrotar o inimigo subversivo, resulta de uma discrepância entre expectativas e realidade, tanto em termos das representações heroicas de seu papel social (salvadores da pátria) quanto da racionalização moral de suas ações (uma guerra levada a cabo pelo bem maior da nação).

Observamos assim as tensas justaposições e disputas entre memória, verdade, justiça e política, que se traduzem como campos semânticos que se 
complementam, alternam e variam em relação aos contextos de enunciação e a seus atores-chave. Após décadas de lutas pelas memórias da ditadura, as violações aos direitos humanos (como colocam as vítimas) ou os excessos (conforme afirmam os acusados) cometidos por razões políticas dificilmente encontram respaldo social. Através de inúmeras ações e lançando mão de uma narrativa que combina humanitarismo e naturalização dos afetos e do parentesco, o movimento de familiares de desaparecidos abriu os caminhos institucionais, científicos e legais para a afirmação da Verdade sobre a ditadura. Os laços de sangue com as vítimas da repressão garantiram capital social e um lugar de transcendência moral para os familiares de desaparecidos, consagrando-os como portadores da Verdade sobre a ditadura. Além disso, o sangue contido em seus corpos (através da genética e da antropologia forense) converteu-se em prova inquestionável da repressão: bancos de sangue oferecem a matéria para comprovar delitos, identificar os restos dos desaparecidos e crianças apropriadas.

A legitimidade das vozes dos afetados imbui-se assim de atributos associados ao campo jurídico e científico (objetividade, neutralidade, veracidade, legalidade), fazendo prevalecer suas memórias e os sentidos que eles atribuem à noção de direitos humanos. ${ }^{24}$ A luta dos familiares por Justiça e Responsabilização, assim como o apelo que tem a afirmação de uma verdade jurídica sobre o passado são, desse modo, cruciais para a consolidação de uma memória pública acerca da ditadura. Trabalhos acadêmicos, sentenças judiciais, evidências materiais (corpos, DNA, edificações, documentos) e os testemunhos dos afetados constituem-se como formas de saber e formas de verdade; antes de tudo, são modos de representação (capazes de produzir efeitos na vida social) que, ao adquirem o estatuto de Verdade, dão contorno e sentido à memória do ocorrido.

Recebido em 26 de setembro de 2016

Aprovado em 07 de dezembro de 2016

Liliana Sanjurjo é pós-doutoranda no Programa de Pós-Graduação em Ciências Sociais (PPCIS), da Universidade do Estado do Rio de Janeiro (UERJ), Rio de Janeiro/RJ, Brasil.E-mail: <lilisanj@yahoo.com.br> 


\section{Notas}

1 Artigo baseado em etnografia sobre o campo de ativismo de familiares de desaparecidos da ditadura argentina, realizada como projeto de doutoramento junto ao PPGAS/Unicamp, com financiamento Fapesp, com desdobramentos numa pesquisa de pós-doutoramento junto ao PPGAS/UFSCar, com financiamento Capes. Ao longo da pesquisa de campo, realizada entre 2009 e 2011, acompanhei as seguintes causas judiciais no Tribunal Federal de Buenos Aires: Causa I Cuerpo del Ejército y Jefes de Area; Causa ABO; Causa ESMA; Causa Automotores Orletti. Ver Sanjurjo (2013). Agradeço a todas e todos os interlocutores durante a pesquisa, sobretudo aos familiares, a quem devo este trabalho. Agradeço também a Bela-Feldman-Bianco pela orientação e inestimável apoio para a realização da pesquisa.

2 Familiares de Desaparecidos y Detenidos por Razones Políticas, Madres de Plaza de Mayo, Abuelas de Plaza de Mayo e H.I.J.O.S. (Hijos e Hijas por la Identidad y la Justicia contra el Olvido y el Silencio).

3 Torna-se ainda pertinente analisar a política como categoria êmica, revelando os sentidos que os sujeitos atribuem às experiências que eles mesmos entendem como políticas, assim como "[...] examinar as relações que indivíduos e grupos estabelecem com a história, com formas de agir e sentir identificadas com gerações anteriores, associadas a tradições" (Neiburg 1995:121).

4 Em seu clássico estudo sobre o processo judicial entre os Barotse na antiga Rodésia, Gluckman (1967) já buscava traçar as relações entre poder e práticas jurídicas, voltando-se para a análise dos modos de controle social nas sociedades tribais.

5 Depoimento de Nora Cortiñas, integrante de Madres de Plaza de Mayo-Línea Fundadora, em 2 de setembro de 2009 em Buenos Aires.

6 Ver Conadep (2009).

7 A ESMA, localizada em Buenos Aires, funcionou como um dos principais centros clandestinos de detenção durante a ditadura militar, por onde passaram cerca de 5 mil pessoas.

8 Para uma discussão sobre a despolitização do relato sobre a ditadura durante o julgamento das Juntas militares, ver Crenzel (2008), Feld (2002) e Jelin (2008).

9 Para um histórico das leis, dos decretos, dos processos judiciais e anistias referentes aos fatos da ditadura argentina, ver Rafecas (2011), Verbitsky (2011) e Yanzon (2011).

10 Apropriado é a categoria empregada para nomear os filhos de desaparecidos sequestrados durante a ditadura (em sua maioria, por membros das próprias forças de repressão), enquanto restituição é o nome dado ao processo de recuperação da Verdade da origem biológica. 
11 A etapa de instrução dos processos penais é constituída por atividades de averiguação e investigação criminal complementar, visando à comprovação judicial da decisão de acusação ou de arquivamento do processo. Com base nas provas reunidas pela procuradoria, são definidos os acusados. Já na etapa oral e pública, são produzidas, de forma ritualizada perante as partes e o público no tribunal, as declarações testemunhais, ao passo que são apresentadas as alegações de procuradores, advogados querelantes e defensores.

12 Para informações sobre número de processos, sentenças, julgamentos finalizados ou em curso, quantidade de acusados, sentenciados, situação processual ou de detenção dos acusados, consultar: <http://www.cels.org.ar/blogs/estadisticas/>.

13 A Convenção para a Sanção e Prevenção do Delito de Genocídio das Nações Unidas, de 1948, excluiu de sua aplicação os grupos políticos, contemplando apenas grupo nacional, étnico, racial ou religioso, exclusão que seria questionada nos anos 1980 pelo Informe Whitaker, pelos escritos do juiz Baltazar Garzón acerca das ditaduras latino-americanas e por análises sobre os tribunais penais internacionais para os genocídios nos Bálcãs e Ruanda. A crítica dirigia-se à inclusão dos grupos políticos no marco da Convenção a fim de abarcar os massacres massivos cometidos contra grupos definidos em termos políticos. Para uma análise sobre o Informe Whitaker, ver Feierstein (2007).

14 Trata-se de uma causa que investigou os crimes cometidos em três centros clandestinos de detenção de Buenos Aires (Club Atlético, Banco e El Olimpo), que funcionaram como um circuito repressivo, sob controle do I Corpo do Exército, entre os anos de 1976 e 1979.

15 Formada pela esquerda peronista, Montoneros foi uma das principais organizações armadas de oposição à ditadura.

16 Sobre a relação entre narrativa, violência e dominação, ver Taussig (1995).

17 Ver Bonasso (1984).

18 Declaração de Jorge Eduardo Acosta durante audiência da Causa ESMA, em 20 de outubro de 2011, no Tribunal Federal de Buenos Aires. Acosta integrou o Grupo de Tarea 33.2 da ESMA.

19 Jorge Rafael Videla, em 21 de dezembro de 2010, em julgamento em Córdoba, que investigou o fuzilamento de 31 presos políticos na Unidade Penitenciária No 1 .

20 Declaração de Jorge Acosta, durante audiência da Causa ESMA, em 20 de outubro de 2011.

21 Declaração de Alfredo Ignacio Astiz, durante audiência da Causa ESMA, em 14 de outubro de 2011, no Tribunal Federal de Buenos Aires. Astiz ganharia notoriedade após se infiltrar no movimento de Madres de Plaza de Mayo, sendo o principal responsável pelo desaparecimento de um grupo de madres e freiras em 1977. 
22 "Asociación de Familiares y Amigos de Presos Políticos Argentinos" e "Asociación de Familiares y Amigos de Víctimas del Terrorismo en Argentina", respectivamente.

23 Discurso de María Cecília Pando, presidente da AFyAPPA, em ato realizado em Buenos Aires em 2009.

24 Verdery (1996) sugere problematizar os sentidos da noção de direitos humanos, distanciando-se de um viés analítico mais normativo para explorar como essa noção (enquanto símbolo político) pode ser apropriada e significada contextualmente. Para análises que versam sobre o debate antropológico entre relativismo cultural e uma noção universal de Direitos Humanos, ver Rapport e Overing (2000). 


\section{Referências bibliográficas}

AGAMBEN, Giorgio. 2008. O que resta de Auschwitz: o arquivo e a testemunha (Homo Sacer III). São Paulo: Boitempo Editorial.

ARENDT, Hannah. 2008a. Eichmann em Jerusalém: um relato sobre a banalidade do mal. São Paulo: Companhia das Letras.

. 2008b. Responsabilidade e julgamento. São Paulo: Companhia das Letras.

BAILEY, Frederick George. 1993. The tactical uses of passion: an essay on power, reason and reality. Ithaca: Cornell University Press.

BONASSO, Miguel. 1984. Recuerdo de la muerte. Buenos Aires: Bruguera Editorial.

BOURDIEU, Pierre. 2003. O poder simbólico. $6^{\mathrm{a}}$ ed. Rio de Janeiro: Bertrand Brasil.

CONADEP. 2009. Nunca Más. Informe de la Comisión Nacional sobre la Desaparición de Personas. $8^{\mathrm{a}}$ ed. Buenos Aires: Eudeba.

CRENZEL, Emilio. 2008. La historia política del Nunca Más. La memoria de los desaparecidos en la Argentina. Buenos Aires: Siglo Veintiuno Editores.

DALEO, Graciela. 2001. "Nosotros, además, somos testigos". Milenio, 5:106-117.

DAS, Veena. 1995. Critical events. An anthropological perspective on contemporary India. New Dheli/Oxford: Oxford University Press.

DURKHEIM, Émile. 1972. Émile Durkheim: selected writings. Cambridge: Cambridge University Press.

FASSIN, Didier. 2008. "Beyond good and evil? Questioning the anthropological discomfort with morals". Anthropological Theory, 8(4):333-344.
.2013. "On resentment and ressentiment: the politics and ethics of moral emotions". Current Anthropology, 54(3): 249-267.

FEIERSTEIN, Daniel. 2007. El genocidio como práctica social: Entre el nazismo y la experiencia argentina. Buenos Aires: Fondo de Cultura Económica.

FELD, Claudia. 2002. Del estrado a la pantalla: las imágenes del juicio a los ex comandantes e Argentina. Madrid: Siglo XXI de España Editores.

FOUCAULT, Michel. 1996. A verdade e as formas jurídicas. Rio de Janeiro: Nau Editora.

GLUCKMAN, Max. 1967. The judicial process among The Barotse of Northern Rhodesia. $2^{\mathrm{a}}$ ed. Manchester: Manchester University Press.

JELIN, Elizabeth. 2008. "La justicia después del juicio: legados y desafíos en la Argentina postdictatorial". In: C. Fico; M. Ferreira \& S. Quadrat (orgs.), Ditadura e democracia na América Latina: balanço histórico e perspectivas. Rio de Janeiro: Editora FGV. pp. 341-360.

LEVI, Primo. 1990. Os afogados e os sobreviventes. Os delitos, as penas, os castigos, as impunidades. São Paulo: Paz e Terra.

MAUSS, Marcel. 2001. "A expressão obrigatória dos sentimentos". In:

Ensaios de sociologia. $2^{\text {a }}$ ed. São Paulo: Editora Perspectiva. pp. 325-338.

NEIBURG, Federico. 1995. "Politização e universidade na Argentina". Novos Estudos CEBRAP, 53:119-135.

PEIRANO, Mariza. 2001. "Rituais como estratégia analítica e abordagem etnográfica"; "A análise antropológica de rituais". In: M. Peirano (org.), O dito e o feito: ensaios de antropologia dos rituais. Rio de Janeiro: Relume e Dumará. pp. 7-42. 
POLLAK, Michael. 1989. "Memória, esquecimento e silêncio". Estudos Históricos, 2(3):3-15.

. 2006. "El testimonio". In: ., Memoria, olvido, silencio: la producción social de identidades frente a situaciones límite. La Plata: Ediciones Al Margen. pp. 53-112.

RAFECAS, Daniel. 2011. "La reapertura de los procesos judiciales por crímenes contra la humanidad en la Argentina". In: G. Andreozzi (org.), Juicios por crimenes de lesa humanidad en Argentina. Buenos Aires: Atuel. pp. 155-176.

RAPPORT, Nigel \& OVERING, Joanna. 2000. "Human rights". In: _. (eds.), Social and cultural anthropology: the key concepts. London \& New York: Routledge Taylor and Francis Group. pp. 167-172.

SALVI, Valentina. 2008. Nem burocratas, nem cruzados: militares argentinos memórias castrenses sobre a repressão. Tese de Doutorado, Universidade Estadual de Campinas, Campinas, São Paulo.

. 2010. "Entre el olvido y la victimización: transformaciones en la narrativa sobre la 'reconciliación nacional'". In: L Pagliani (org.), La sociedad argentina hoy frente a los años '70. Buenos Aires: Eudeba. pp. 113-142.

SANJURJO, Liliana Lopes. 2013. Sangue, identidade e verdade: memórias sobre o passado ditatorial na Argentina. Tese de Doutorado, Universidade Estadual de Campinas, Campinas, São Paulo.

SARLO, Beatriz. 2007. Tempo passado: cultura da memória e guinada subjetiva. São Paulo/ Belo Horizonte: Companhia das Letras/Editora UFMG.

SIKKINK, Kathryn. 2011. "A era da responsabilização: a ascensão da responsabilização penal individual". In: L. Payne; P. Abrão \& M. Torelly (orgs.), A anistia na era da responsabilização: o Brasil em perspectiva internacional e comparada. Brasília: Ministério da Justiça/ Comissão de Anistia. pp. 34-75.

SLEPOY, Carlos. 2011. "Impunidad y justicia universal en relación con crímenes lesivos para la humanidad. Los juicios en España". In: G. Andreozzi (org.), Juicios por crimenes de lesa humanidad en Argentina. Buenos Aires: Atuel. pp. 101-118.

TAUSSIG, Michael. 1995. Xamanismo, colonialismo e o homem selvagem. Rio de Janeiro: Paz e Terra.

TIMERMAN, Jacobo. 2000. Preso sin nombre, celda sin número. Buenos Aires: Ediciones De La Flor.

TISCORNIA, Sofia \& PITA, María Victoria. 2005. "Presentación". In:

(orgs.), Derechos humanos, tribunales y policías en Argentina y Brasil: estudios de antropología jurídica. Buenos Aires: Antropofagia. pp. 7-9.

TURNER, Victor. 1974. O processo ritual: estrutura e antiestrutura. Petrópolis: Editora Vozes.

. 1985. Drama, fields and metaphors: symbolic action in human society. Ithaca/London: Cornell University Press.

VECCHIOLI, Virginia. 2001. "Políticas de la memoria y formas de clasificación social. Quiénes son las víctimas del terrorismo de Estado en la Argentina?". In: B. Groppo \& P. Flier (orgs.), La imposibilidad del olvido: recorridos de la memoria en Argentina, Chile y Uruguay. La Plata: Ediciones Al Margen. pp. 83-102. . 2005. "La nación como familia. Metáforas políticas del movimiento argentino de derechos humanos". In: S. Frederic \& G. Soprano (orgs.), Cultura y política en etnografías sobre la Argentina. Quilmes: Universidad Nacional de Quilmes Editorial. pp. 241-269. 
VERBITSKY, Horacio. 2011. "Entre olvido y memoria". In: G. Andreozzi (org.), Juicios por crimenes de lesa humanidad en Argentina. Buenos Aires: Atuel. pp. 33-42.

VERDERY, Katherine. 1996. What was socialism, and what comes next? Princeton/New Jersey: Princeton University Press.

. 1999. The political lives of dead bodies: reburial and postsocialist change. New York: Columbia Uni-
VIANNA, Adriana. 2005. "Direitos, moralidades e desigualdades: considerações a partir de processos de guarda de crianças". In: R. Lima (org.), Antropologia e direitos humanos 3. Niterói: Editora da Universidade Federal Fluminense. pp. 13-68.

YANZON, Rodolfo. 2011. "Los juicios desde el fin de la dictadura hasta hoy". In: G. Andreozzi (org.), Juicios por crimenes de lesa humanidad en Argentina. Buenos Aires: Atuel. pp. 
“ LOS JUZGA UN TRIBUNAL, LOS CONDENAMOS TODOS": DOS CONFLITOS PELAS MEMÓRIAS, MORALIDADES E VERDADE NOS TRIBUNAIS ARGENTINOS

\section{Resumo}

Há mais de três décadas, familiares de desaparecidos da ditadura militar argentina se engajam em ações políticas para exigir Justiça pelas violações aos direitos humanos cometidas durante a repressão. Com a anulação das leis de anistia em 2005, abriram-se os caminhos legais para a responsabilização penal. Desde então, as narrativas sobre o passado entraram definitivamente em cena (e em disputa) nos tribunais do país. Baseado em etnografia dos julgamentos de delitos de lesa humanidade na Argentina, o artigo analisa como vítimas, agentes do Estado acusados de violações e atores judiciais converteram os tribunais em lugar privilegiado para a afirmação de sentidos ao passado ditatorial. Conduzindo uma análise mais encantada da política e seu simbolismo (que considera a dimensão afetiva e existencial da ação humana), o intuito é problematizar como a cena judicial vem se desempenhando como espaço de luta para a produção do saber e verdade sobre a ditadura na Argentina.

Palavras-chave: Memória; Ditadura Militar; Direitos Humanos; Política; Moralidades.

\section{“LOS JUZGA UN TRIBUNAL, LOS CONDENAMOS TODOS":} CONFLICTOS POR LAS MEMORIAS, MORALIDADES Y VERDAD EN LOS TRIBUNALES ARGENTINOS

\section{Resumen}

Desde fines de los años 1970, familiares de desaparecidos de la dictadura militar argentina emprendieron acciones políticas para exigir Justicia por las violaciones de los derechos humanos cometidas durante la represión. Con la anulación de las leyes de amnistía en 2005, quedaron abiertos los caminos legales para la responsabilización penal. Desde entonces las narrativas sobre el pasado de violencia entraron definitivamente en escena (y en disputa) en los tribunales del país. Fundamentado en la investigación etnográfica llevada a cabo en los juicios de crímenes de lesa humanidad en Argentina, el artículo analiza como las víctimas, los agentes del Estado acusados de violaciones y los actores judiciales han convertido los tribunales en lugar privilegiado para la afirmación de sentidos del pasado dictatorial. La propuesta es conducir un análisis de la política y su simbolismo, que considera sobre todo la dimensión afectiva, moral y existencial de la acción humana, para problematizar cómo la escena judicial se ha transformado en espacio de lucha para la producción de la verdad sobre la dictadura en Argentina. Palabras clave: Memoria; Dictadura militar; Derechos humanos; Política; Moralidades. 
“THE COURT JUDGES THEM, WE

ALL CONDEMN THEM" : CONFLICTS OVER MEM ORIES, MORALITIES AND TRUTH IN ARGENTINIAN COURTS

\section{Abstract}

For over three decades, the families of those who disappeared during Argentina's Military Dictatorship have been engaged in political actions that demand justice for human rights violations during the repression. Legal means of achieving penal liability have opened up since the annulment of amnesty laws in 2005. Since then, narratives of the past have definitely taken centre stage - and, hence, been in dispute-in the Argentinean courts. Based on an ethnography of "trials for crimes against humanity", this article analyses how victims, State agents accused of violations and judicial actors have converted the courts into a privileged place for the attribution of meanings to the dictatorial past. It questions how the judicial system is being converted into an arena for disputes over the production of knowledge and truth concerning the military dictatorship in Argentina, through an analysis of the enchantment of politics and its symbolism that takes into account the emotional and existential aspects of human action.

Key-words Memory; Military Dictatorship; Human Rights; Politics; Moralities. 